\title{
Protective Effect of Nigella Sativa in Alloxan Induced Diabetic Rats
}

\author{
Ahmed Mohamed Mahmoud*, Bahaa Kenawy Abuel- Hussein Abdel- \\ Salam**, Wafaey Gomaa*** \\ *Biochemistry and *** Pathology Departments, Faculty of Medicine, \\ **Zoology Department, Faculty of Science, Minia University
}

\begin{abstract}
Oxidative stress has been suggested to be a contributory factor in complication of diabetes mellitus. There are many reports indicating the change in parameter of oxidative stress in alloxan induced diabetic rats, we aimed to find if the oxidative stress which occurs in pancreas has a role in development of diabetes mellitus. This was done by measuring plasma lipid profile, insulin, interleukin 8 (IL-8), transforming growth factor $\alpha$ and reduced glutathione content in pancreas. The study was carried on 30 rats, classified into 3 groups: control group, diabetic group in which diabetes was induced by a single intraperitoneal (i.p) injection of alloxan monohydrate (120 mg/kg of body weight), treated group in which rats were given Nigella sativa extract i.p. $(0.2 \mathrm{ml} / \mathrm{kg} /$ day $), 2$ week before injection of alloxan, these injections were continued daily until the end of the study (for 4 weeks). The results showed significant increase of plasma glucose, total cholesterol, triglycerides, low density lipoprotein cholesterol (LDLc), interleukin 8 and transforming growth factor $\alpha$ in diabetic group, with significant decrease in high density lipoprotein cholesterol $(H D L c)$, reduced glutathione content in pancreas, and insulin level in diabetic group. The treated groups showed significant reduction in plasma glucose, total cholesterol, triglycerides, LDLc, interleukin 8 and transforming growth factor $\alpha$ with significant increase in HDLc, reduced glutathione content in pancreas and insulin level. It could be concluded that Nigella sativa treatment for 1.5 months in rats with experimentally alloxan-induced diabetes increase the activity of the anti-oxidant defense system. Thus, it could be used as an anti-diabetic complement in cases of diabetes mellitus.
\end{abstract}

Abbreviation

Nigella sativa (NS), interleukin-8 (IL-8), low-density lipoprotein cholesterol (LDLc), Transforming growth factor alpha $(T G F-\alpha)$, epidermal growth factor (EGF), Institutional Animal Ethics Committee (IAEC), high density lipoprotein cholesterol $(H D L c)$, low density lipoprotein cholesterol (LDLc), Triglycerides (TG), insulindegrading enzyme (IDE)

Key words: Alloxan and Nigella Sativa in rats

\section{INTRODUCTION}

Alloxan and streptozotocin selectively damage pancreatic $\beta$-cells and exhibit the most potent diabetogenicity. They have been widely used for induction of experimental diabetes mellitus. 
Understanding the mechanisms of action of the typical diabetogenic agent is important for elucidating the causes of diabetes. Thus, many mechanisms have been considered over the last 40 years for the specific $\beta$-cell toxicity of alloxan. The mechanism increasingly accepted is the fragmentation of nuclear DNA of pancreatic $\beta$-cells which seems to be important for the development of diabetes and is supposed to result from the accumulation of superoxide or hydroxyl radicals in the case of alloxan. Renold had evidenced that alloxan stimulates $\mathrm{H}_{2} \mathrm{O}_{2}$ generation which induces DNA breaks ${ }^{(1)}$.

A single dose of alloxan (100 $\mathrm{mg} / \mathrm{kg} \mathrm{b.wt}$.) produced a decrease in insulin level, hyperglycemia, elevated total lipids, triglycerides, cholesterol, decreased HDLc and elevated hepatic glucose-6-phosphatase activity. Concurrent with these changes, there was an increase in the concentration of malondialdehyde in the liver ${ }^{(2)}$.

South Asia and Bangladesh harvest a rich source of herbs, trees of medicinal value. Nigella sativa (NS) is one of such herbal products which have been in use as a spice from ancient times. Its medicinal value to treat various diseases is well-known. It is antibacterial ${ }^{(3)}$ and antidiabetic ${ }^{(4)}$.

The seed of NS has been used for centuries in the Middle East, Northern Africa, the Far East, and Asia as a traditional treatment for asthma. NS contains $30 \% \mathrm{w} / \mathrm{w}$ of a fixed oil, and $0.40-0.45 \% \mathrm{w} / \mathrm{w}$ of a volatile oil. The volatile oil has been shown to contain $18.4-24 \%$ thymoquinone and $46 \%$ monoterpenes, such as p-cymene $\& \alpha$ pinene ${ }^{(5)}$.
Antioxidants present in NS seeds include selenium and $\alpha$-tocopherol, all trans retinol, thymoquinone and thymol ${ }^{(6)}$. The antioxidant effects are attributed to thymoquinone, a main constituent of the volatile oil of NS. Thymoquinone inhibits irondependent microsomal lipid peroxidation and is a potent superoxide anion scavenger ${ }^{(7)}$.

Lipid peroxidation is an autocatalytic mechanism leading to oxidative destruction of cellular membranes. Their destruction can lead to cell death and also to the production of toxic and reactive aldehyde metabolites called free radicals. It has been suggested that free radical production increases due to the increased oxidative stress in diabetes mellitus ${ }^{(8)}$.

It is proposed that one of the adipocyte-derived cytokines is interleukin-8 (IL-8) which is produced mainly by macrophages and monocytes and plays a role in modulating an inflammatory response. Inflammation might contribute to the pathogenesis of atherosclerosis ${ }^{(\mathbf{9})}$.

Oxidized low-density lipoprotein (ox-LDL) particles are able to stimulate production and secretion of IL- 8 by macrophages and high levels of IL-8 in macrophage-derived human foam cells were found. IL- 8 is a potent chemoattractant and may be responsible for the recruitment of neutrophils and $\mathrm{T}$ lymphocytes into the subendothelial space. It also induces adhesion of monocytes to endothelium and migration of vascular smooth muscle cells ${ }^{(10)}$. Elevated serum IL-8 levels were found in type 1 and 2 diabetic patients, and it was suggested that this cytokine might 
also contributes to the development of diabetic macroangiopathy ${ }^{(11)}$.

Transforming growth factor alpha (TGF- $\alpha$ ) is a 50 amino acid polypeptide which is structurally related to epidermal growth factor (EGF) and binds to the same receptor. TGF- $\alpha$ was long thought to be a fetal form of epidermal growth factor, but it is now known to be present also in normal adult tissues as well as in malignant tumors (12). Many pancreatic cancer cell lines express TGF- $\alpha$ and over express epidermal growth factor receptor (EGF-R) mRNA. In addition, EGFR-like immunoreactivity can be found from ducts and acini in normal adult pancreas ${ }^{(13)}$.

During the second trimester, exocrine cells are distinguished from the ductal epithelium and by the $22^{\text {nd }}$ gestation week lobules of exocrine acini and islets are separated by abundant mesenchyme. Blood vessels are formed between acini and islets. Lipase, amylase and tryptic activity can be detected from the $22^{\text {nd }}$ gestation week. So, differentiation and cellular proliferation take place concurrently with strong expression of TGF- $\alpha$ in both the exocrine and endocrine pancreas. The expression of the TGF- $\alpha$ receptor in pancreas further suggests that TGF- $\alpha$ may function as an auto and paracrine growth factor regulating these epithelial mesenchymal interactions or it may function mitogenically on the acini, ducts and islets ${ }^{(14)}$.

TGF- $\alpha$ like immunoreactivity was found also in the pancreatic ducts. The ductally produced TGF- $\alpha$ might flow into duodenum and function as paracrine, increasing the TGF- $\alpha$ production of the pancreatic cells and thereby increase their growth rate ${ }^{(15)}$.

The present study was undertaken to determine whether the pancreas is subjected to oxidative damage during diabetes, and to examine the accompanying changes in antioxidant status in order to elucidate its role in the pathogenesis of that disease. In addition, we explored whether NS treatment protects against pancreatic $\beta$-cell damage in alloxan-induced diabetic rats.

\section{MATERIALS \& METHODS}

\section{Plant Material and Extraction Procedure}

The NS seeds were purchased from a local herb store in Egypt. Plant extract of NS seeds was prepared using the method described by AlAwadi ${ }^{(\mathbf{1 6})}$. Suspension of NS seeds in drinking water was prepared fresh daily. The seeds (50 g.) were boiled in drinking water $(1000 \mathrm{ml})$ for 10 minutes, then filtered through four layers of surgical gauze to yield $0.4 \%$ V/V. Filtered extract was used for the experiment.

\section{Treatment of rats}

Thirty male rats, weighting 150 $250 \mathrm{~g}$ and of average age 4 months, were used. The experiment was conducted according to the ethical norm approved by Institutional Animal Ethics Committee (IAEC). Rats were divided into three experimental groups (control, diabetic and diabetic + NS treated), each group contained 10 rats.

Rats in all groups were provided with food (ground wheat, soybeanmeal-based diet) and water ad libitum, at the end of experimental period, the 
rats were anesthetized and sacrificed. Blood samples were collected in tubes containing $\mathrm{K}_{2}$ EDTA and sodium fluoride. The plasma was stored at $4^{\circ} \mathrm{C}$ until analysis was performed, pancreas was taken for measurement of reduced glutathione contents and pathological examination.

Diabetes was induced in diabetic and diabetic NS treated groups by a single intraperitoneal (i.p) injection of alloxan monohydrate $(120 \mathrm{mg} / \mathrm{kg}$ of body weight), (Sigma Chemical Co., USA), freshly dissolved in $5 \mathrm{mmol}$ sterile normal saline ${ }^{(\mathbf{1 7})}$. The rats were fasted $12 \mathrm{~h}$ before and $12 \mathrm{~h}$ after alloxan injection. The control group was injected with sterile normal saline. Two weeks prior to induction of diabetes, the diabetic NS-treated group was given NS extract i.p. (0.2 $\mathrm{ml} / \mathrm{kg} /$ day). These injections were continued daily until the end of the study (for 4 weeks). The dose of NS was chosen on the basis of a previous study ${ }^{(18)}$.

Three days after the alloxan treatment, the development of diabetes was confirmed by measuring plasma glucose levels in blood samples taken from a tail vein. Rats with blood glucose levels $\geq 250 \mathrm{mg} / \mathrm{dl}$ were considered to be diabetic. Plasma glucose levels in the control animals remained normal throughout the study. Diabetes mellitus was confirmed by the use of an Ames One Touch Glucometer (LifeScan; Johnson and Johnson, New Brunswick, NJ).

\section{Biochemical analysis}

All the chemicals used in the present experiment were purchased from Sigma Chemical Company (St
Louis, MO, USA) and they were of analytical grade.

At the end of the experiment, rats in all three groups were fasted for $12 \mathrm{~h}$ and blood samples were taken for determination of glucose ${ }^{(\mathbf{1 8})}$, total cholesterol (19), HDLc ${ }^{(20)}$, LDLc ${ }^{(21)}$, $\mathrm{TG}^{(\mathbf{2 2})}, \mathrm{IL} 8^{(23)}$, TGF $\alpha^{(24)}$ and insulin level.

All kits used for determination of total cholesterol, HDLc, LDLc, TG, glucose, were obtained from Egyptian Company for Biotechnology, Cairo , Egypt.

All spectrophotometric measurements were carried out by Spekol 11 UV visible spectrophotometer ACHTUNG, Vor offnen, Netzstecher Ziehen).

Insulin level in serum were measured by radioimmunoassay Rat/Mouse Insulin ELISA kit ,Cat. \# EZRMI-13K (USA).

TGF $\alpha$ was determined by radioimmunoassay (ELISA quantikine (R\&D) USA.

Assay of IL-8 in plasma by rat IL-8 ELISA kit, (Bender Med-system GmbH, Cat No. CSB- EO- 7273 r (96 test) Austria)

At the end of study, pancreas was excised and its weight was recorded. Tissue homogenate of pancreas:

The pancreas was homogenized by teflon homogenizer with a homogenizing buffer: Tris $0.363 \mathrm{mg}$, sucrose $21.39 \mathrm{~g}$. benzimidine $0.078 \mathrm{~g}$., beta mercaptoethanol $500 \mu \mathrm{l}(0.2 \%)$, $\mathrm{pH} 7.5$, centrifuged at $4,000 \mathrm{rpm}$ for $15 \mathrm{~min}$ at $4^{\circ} \mathrm{C}$, the supernatant removed for assay and stored at $80^{\circ} \mathrm{C}$. -Assay of reduced glutathione ${ }^{(25)}$ content of pancreas using the kit (colormetric methods: Biodiagnostic) 


\section{Histological procedure:}

Pancreas was dissected out, cut into small pieces and were fixed in $10 \%$ formalin. They were embedded in paraffin and were cut into $5 \mu \mathrm{m}$ thickness in microtome. These sections were collected in slides and then stained with Hematoxylin and Eosin, the stained sections were examined under low and high power by using an Olympus microscope.

\section{Statistical Analysis}

The data were expressed with SPSS 13 software as the mean \pm standard deviation (SD), Analysis of variance (ANOVA) was used to compare the data in 3 groups of rats and was considered significant at $(P<0.05)$. Independent t-test, for parametric quantitative data.

\section{RESULTS}

Table 1, illustrates the mean \pm SD of plasma glucose level in different groups.

Alloxan significantly increased plasma glucose compared with control groups ( $\mathrm{p}<0.05$ ) Fig. (1) plasma glucose significantly decreased after treatment for 1.5 month compared with alloxan groups, also insulin level significantly decreased in alloxan groups $(\mathrm{p}<0.05)$ compared with control groups and significantly increased after treatment with NS for 1.5 month compared with alloxan groups.
Table 2, illustrates the mean \pm SD of the lipid profile of the study groups.

A statistically significant increase in TC, TG and LDLc concentration occurred in alloxan induced diabetic group versus control groups ( $\mathrm{P}$ value $<0.05$ ) and significantly decreased after treatment compared with alloxan group.

A statistically significant decrease in HDL concentration of alloxan induced diabetic group versus control groups ( $\mathrm{P}$ value $<0.05)$ and significantly increased after treatment compared with alloxan groups.

Table 3, illustrates significant decrease in reduced glutathione in alloxan induced diabetic group compared with control groups ( $\mathrm{p}$ $<0.05$ ) and significantly increased after treatment compared with alloxan group.

A significant increase in plasma IL-8 in alloxan induced diabetic group ( $\mathrm{P}$ value $<0.05$ ) compared with control group and significant decrease after treatment compared with alloxan group.

There were also significant increase in TGF- $\alpha$ in alloxan induced diabetic group ( $\mathrm{P}$ value $<0.05)$ compared with control group and significantly decreased after treatment compared with alloxan group.

Fig. (2) shows pathology of pancreas in control group, diabetic group and treated group. 
Table (1): Plasma glucose and insulin levels in the studied groups

\begin{tabular}{|l|c|c|c|c|c|c|}
\hline \multirow{2}{*}{$\begin{array}{c}\text { Diabetic } \\
\text { Laboratory } \\
\text { tests }\end{array}$} & $\begin{array}{c}\text { Control } \\
\text { Group } \\
\text { No=10 }\end{array}$ & $\begin{array}{c}\text { Alloxan } \\
\text { Group } \\
\text { No=10 }\end{array}$ & $\begin{array}{c}\text { Treated } \\
\text { Group } \\
\text { No=10 }\end{array}$ & \multirow{2}{*}{ P1 } & \multirow{2}{*}{ P2 } & \multirow{2}{*}{ P3 } \\
\cline { 2 - 7 } $\begin{array}{l}\text { Glucose mg/dl } \\
\text { Range } \\
\text { Mean } \pm \text { SD }\end{array}$ & $60-90$ & $197-300$ & $90-113$ & $<0.0001^{*}$ & $<0.0001^{*}$ & $<0.0001^{*}$ \\
\hline $\begin{array}{l}\text { Insulin } \boldsymbol{\mu} \text { Unit/ml } \\
\text { Range }\end{array}$ & $76.4 \pm 9.3$ & $270.1 \pm 28.9$ & $102.3 \pm 7.2$ & & & \\
Mean \pm SD & $9-17$ & $2-6$ & $8-12$ & $<0.0001^{*}$ & $0.005^{*}$ & $<0.0001^{*}$ \\
\hline
\end{tabular}

$P 1=$ Control vs Alloxan,

$P 2=$ Control $v$ s treated with Nigela.

P3 $=$ Alloxan vs treated with Nigela

Independent t-test, for parametric quantitative data

* Significant if $p$ value $<\mathbf{0 . 0 5}$.

Table (2): Plasma lipid profile of the studied groups

\begin{tabular}{|c|c|c|c|c|c|c|}
\hline \multirow{2}{*}{$\begin{array}{l}\text { Lipid } \\
\text { profile }\end{array}$} & \multicolumn{3}{|c|}{$\begin{array}{c}\text { Study groups } \\
N_{0}=\mathbf{3 0}\end{array}$} & \multirow[b]{2}{*}{ P1 } & \multirow[b]{2}{*}{$\mathbf{P 2}$} & \multirow[b]{2}{*}{ P3 } \\
\hline & $\begin{array}{l}\text { Control } \\
\text { Group } \\
\text { No=10 } \\
\end{array}$ & $\begin{array}{c}\text { Alloxan } \\
\text { Group } \\
\mathrm{No}=10\end{array}$ & $\begin{array}{l}\text { Treated } \\
\text { Group } \\
\mathrm{No}=10 \\
\end{array}$ & & & \\
\hline $\begin{array}{l}\text { TC mg/dl } \\
\text { Range } \\
\text { Mean } \pm \text { SD }\end{array}$ & $\begin{array}{c}50-133 \\
91.9 \pm 24.8\end{array}$ & $\begin{array}{c}200-312 \\
279.8 \pm 31.5\end{array}$ & $\begin{array}{l}155-170 \\
163.9 \pm 6\end{array}$ & $<0.0001 *$ & $<0.0001 *$ & $<0.0001^{*}$ \\
\hline $\begin{array}{l}\text { TG mg/dl } \\
\text { Range } \\
\text { Mean } \pm \text { SD }\end{array}$ & $\begin{array}{c}58-164 \\
120.1 \pm 36.2 \\
\end{array}$ & $\begin{array}{c}134-220 \\
178.1 \pm 24.9 \\
\end{array}$ & $\begin{array}{c}110-197 \\
150 \pm 29.9 \\
\end{array}$ & $0.001 *$ & 0.059 & $0.035^{*}$ \\
\hline $\begin{array}{l}\text { LDL mg/dl } \\
\text { Range } \\
\text { Mean } \pm \text { SD }\end{array}$ & $\begin{array}{c}50-83 \\
60.7 \pm 12.2 \\
\end{array}$ & $\begin{array}{c}140-190 \\
181.3 \pm 14.9 \\
\end{array}$ & $\begin{array}{c}98-120 \\
106.8 \pm 6.3 \\
\end{array}$ & $<0.0001 *$ & $<0.0001 *$ & $<0.0001^{*}$ \\
\hline $\begin{array}{l}\text { HDL mg/dl } \\
\text { Range } \\
\text { Mean } \pm \text { SD }\end{array}$ & $\begin{array}{c}22-58 \\
33 \pm 11.2\end{array}$ & $\begin{array}{c}20-37 \\
27 \pm 5.3\end{array}$ & $\begin{array}{c}35-48 \\
41.6 \pm 5.1\end{array}$ & 0.14 & $0.04 *$ & $<0.0001^{*}$ \\
\hline
\end{tabular}

$P 1=$ Control vs Alloxan,

$P 2=$ Control $v$ s treated with Nigela.

P3 $=$ Alloxan vs treated with Nigela

Independent t-test, for parametric quantitative data

* Significant if $\mathrm{p}$ value $<0.05$.

TC: Total Cholesterol TG: Triglycerides

LDL: Low Density Lipoproteins HDL: High Density Lipoproteins 
Table (3): Plasma IL-8,TGF $\alpha$ and pancreatic reduced glutathione in the studied groups.

\begin{tabular}{|c|c|c|c|c|c|c|}
\hline \multirow{2}{*}{$\begin{array}{c}\text { Laboratory } \\
\text { tests }\end{array}$} & \multicolumn{3}{|c|}{$\begin{array}{c}\text { Study groups } \\
\text { No=30 }\end{array}$} & \multirow[b]{2}{*}{ P1 } & \multirow[b]{2}{*}{$\mathbf{P 2}$} & \multirow[b]{2}{*}{ P3 } \\
\hline & $\begin{array}{l}\text { Control } \\
\text { Group } \\
\text { No=10 }\end{array}$ & $\begin{array}{l}\text { Alloxan } \\
\text { Group } \\
\text { No=10 }\end{array}$ & $\begin{array}{l}\text { Treated } \\
\text { Group } \\
\text { No=10 }\end{array}$ & & & \\
\hline $\begin{array}{l}\text { GSH , mg/g tissue } \\
\text { Range } \\
\text { Mean } \pm \text { SD }\end{array}$ & $\begin{array}{c}0.9-1.5 \\
1.2 \pm 0.18\end{array}$ & $\begin{array}{c}0.5-0.9 \\
0.69 \pm 0.12\end{array}$ & $\begin{array}{c}0.8-1 \\
0.9 \pm 0.06\end{array}$ & $<0.0001 *$ & $<0.0001 *$ & $<0.0001^{*}$ \\
\hline $\begin{array}{l}\text { IL-8 pg/dl } \\
\text { Range } \\
\text { Mean } \pm \text { SD }\end{array}$ & $\begin{array}{c}89-150 \\
124.9 \pm 20 \\
\end{array}$ & $\begin{array}{c}120-210 \\
178.7 \pm 27.4\end{array}$ & $\begin{array}{c}100-182 \\
152.6 \pm 34.4 \\
\end{array}$ & $<0.0001 *$ & $0.041 *$ & 0.077 \\
\hline $\begin{array}{l}\text { TGF alpha } \mathrm{pg} / \mathrm{ml} \\
\text { Range } \\
\text { Mean } \pm \mathrm{SD}\end{array}$ & $\begin{array}{c}0.6-7 \\
3.32 \pm 2.2\end{array}$ & $\begin{array}{c}22-38 \\
29.2 \pm 4.8 \\
\end{array}$ & $\begin{array}{l}11.3-17.5 \\
14.4 \pm 2.3\end{array}$ & $<0.0001 *$ & $<0.0001^{*}$ & $<0.0001 *$ \\
\hline
\end{tabular}

GSH : Reduced glutathione

IL-8: Interleukin 8

$P 1=$ Control vs Alloxan,

$P 2=$ Control vs treated with Nigela.

$P 3=$ Alloxan vs treated with Nigela

Independent t-test, for parametric quantitative data

* Significant if $p$ value $<0.05$.

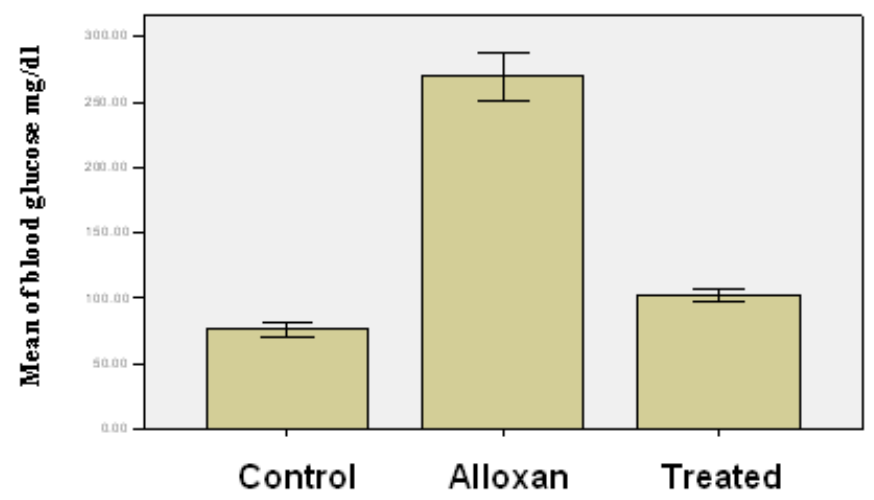

Fig. (1): Plasma glucose levels of the studied groups.

A statistically significant increase in glucose concentration in alloxan groups versus control groups $(\mathrm{P}$ value $<0.05)$ and significantly decrease after treatment compared with alloxan groups. 

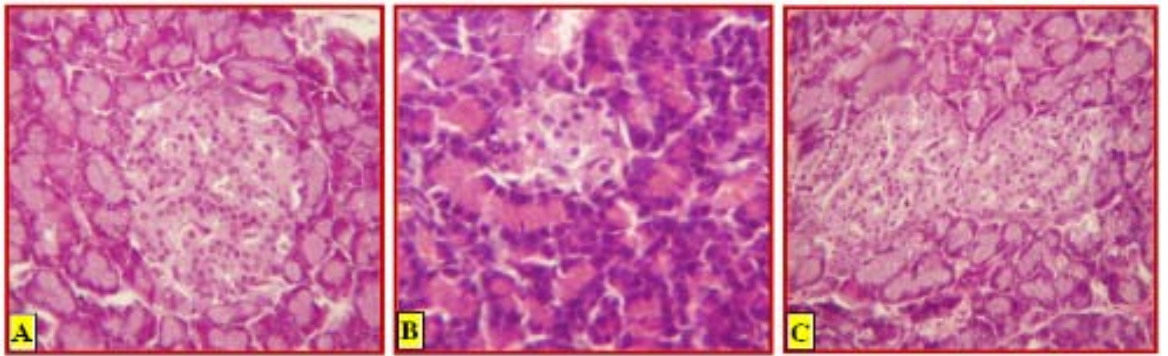

Fig. (2): A) shows normal cells in the islet of Langerhans in control group. B) shows diabetic group with shrunken islets of Langerhans and degeneration. C) shows treated group with normal restoration islets of Langerhan to normal. Sections were stained with $H \& E$ with magnification 200X.

\section{DISCUSSION}

In the current study, the effect of NS on oxidative stress and $\beta$-cell damage was examined in alloxaninduced diabetic rats. The mechanisms behind free radicals and the possible role of oxidative stress in the pathogenesis of diabetes and diabetic complications have been studied for years in patients and animal models. Diabetics and experimental animal models exhibit high oxidative stress due to persistent and chronic hyperglycemia, which depletes the activity of the antioxidative defense system and thus promotes de novo generation of free radicals ${ }^{(27)}$.

Alloxan treatment produced a significant elevation in plasma glucose concentration. Alloxan injection show statistically significant increase in glucose concentration versus control groups ( $\mathrm{P}$ value $<0.05$ ) and decrease significantly after treatment compared with alloxan groups.

Alloxan injection significantly increased TC, TG, and LDLc. The abnormally high concentration of plasma lipids in diabetes mellitus is mainly due to an increase in the mobilization of free fatty acids from the peripheral fat depots, since insulin inhibits the hormone sensitive lipase. The marked hyperlipidemia that characterizes the diabetic state may therefore be regarded as a consequence of the uninhibited actions of lipolytic hormones on the fat depots. Excess of fatty acids in plasma produced by alloxan promotes the liver conversion of some fatty acids to phospholipids and cholesterol esters. These two substances, along with excess of TG formed in the liver, may be discharged into lipoproteins in the blood (28). Administration of NS extract to diabetic rats reversed all the above mentioned changes and improved the HDL levels.

It was demonstrated that alloxan stimulate $\mathrm{H}_{2} \mathrm{O}_{2}$ generation that induced DNA strand breaks. These findings may support Okamoto's proposal that alloxan induces diabetes mellitus through the following biochemical events: $\mathrm{H}_{2} \mathrm{O}_{2}$ generation, DNA strand breaks, diabetes mellitus. 
Alloxan has been known to be diabetogenic and induces DNA strand breaks in isolated rat pancreatic islets in vitro and in vivo to cause diabetes mellitus (29)

In the present work treatment with NS for 1.5 month in male rats improved the reduced pancreatic glutathione concentrations, and NS administration has stimulated the enzymes which enhance reduced glutathione synthesis or inhibit the enzymes which metabolize reduced glutathione ${ }^{(30)}$.

Reduced glutathione is present in the islet $\beta$ cells and protects the membrane against oxidative damage by regulating the redox status of protein in the membrane ${ }^{(\mathbf{3 1})}$.

The mechanism of action of NS on decreasing the glucose concentration in DM is unknown. Since degeneration and necrosis of the islets were observed in the pancreas of both diabetic and NS treated rabbits, the decrease of glucose concentration could not be due to increased insulin release from the pancreas. More studies are needed to demonstrate its mechanism of action. Oral supplementation of NS before or after alloxan treatment in previous study resulted in lower plasma glucose levels, higher serum insulin values and an improved lipid profile as compared with alloxan alone ${ }^{(\mathbf{3 2})}$.

NS treatment protected the majority of the Langerhans islet cells. These results support recent findings regarding the role and use of natural antioxidants as a means of preventing oxidative damage in diabetes due to high oxidative stress ${ }^{(33)}$.

The localization of TGF- $\alpha$ into $\beta$ cells is interesting. These cells are known to secrete a variety of proteins besides insulin. Insulin co localization with TGF- $\alpha$ and the existence of insulin-degrading enzyme (IDE) that degrades insulin as well as TGF- $\alpha^{(34)}$.

A significant increase in TGF $\alpha$ concentration was shown in alloxan group versus control group ( $\mathrm{P}$ value $<0.05)$ and decreased significantly after treatment compared with alloxan groups.

It was demonstrated that high glucose concentrations are able to stimulate IL-8 production from cultured endothelial cells, and in diabetic subjects circulating IL- 8 is related to a degree of metabolic control. Although fasting IL-8 levels were not related to fasting glucose concentrations ${ }^{(\mathbf{1 1}) .}$

A significant increase in IL-8 concentration occurred in alloxan group versus control group ( $\mathrm{P}$ value $<0.05)$ and significantly decreased after treatment compared with alloxan group.

These findings are of interest since chemokines such as IL-8 has been suggested to be involved in the pathogenesis of diseases associated with excess amounts of adipose tissue e.g. atherosclerosis and cardiovascular disease. In addition, circulating levels of IL-8 have been reported to be increased in patients with type 1 and type 2 diabetes linking these chemokines with insulin resistance ${ }^{(11)}$.

It could be concluded that NS treatment for 1.5 months in rats with experimentally induced diabetes by alloxan increase the activity of the anti-oxidant defense system. Thus, it could be used as an anti-diabetic complement in cases of diabetes mellitus. 


\section{REFERENCES}

1. Renold, A. E. (1988): Streptozotocin and alloxan in experimental diabetes: Comparison of the two models in rats Diabetes Annu. 4: 592-608.

2. El-Missiry, M. and El-Gindy $M$. (2000): Amelioration of alloxan induced diabetes mellitus and stress in rats by oil of Eruca sativa seeds. Ann. Nutr. Metab., 44: 97-100.

3. Ara N. (1999): Antimicrobial activity of the volatile oil of Nigella sativa Lnn. seeds. M.Phil Thesis, Dhaka: Bangabandhu Sheikh Mujib Medical University,

4. Uddin N, Dewan ZF, Zaman M, Nasir M, Moshiuzzaman M, and Saha RR. (2005): Comparative study of hypoglycemic effects of crude Nigella sativa Linn. (kalajira) and its ethanol extract on STZ induced diabetic rats. J. Med. Sci. Res., 5: 27-32.

5. Mehmet K, Omer C., and Ahmet K. (2004): Effects of Nigella sativa on oxidative stress and beta cell damage in alloxan induced diabetic rats. The Anatomical Record Part A 279A: 685-691.

6. Kanter M, Coskun O, and Uysal H. (2006): The antioxidative and antihistaminic effect of Nigella sativa and its major constituent, thymoquinone on ethanol-induced gastric mucosal damage. Arch Toxicol., 80: 217-224.

7. El-Saleh SC, Al-Sagair OA, and Al-Khalaf MI. (2004): Thymoquinone and Nigella sativa oil protection against methionine- induced hyperhomocysteinemia in rats. International Journal of Cardiology 93: 19-23.

8. Meral I. Yener $T$ and Kahraman T (2001): Effect of Nigella sativa on glucose concentration, lipid eroxidation, anti-oxidant defense system and liver damage in experimentally induced diabetic rabbits. Vet. Med. A, 48: 593-599.

9. Hotamisligil GS, Arner P, Atkinson RL, and Spiegelman BM (1997): Differential regulation of the p80 tumor necrosis factor receptor in human obesity and insulin resistance. Diabetes, 46: 451-455.

10. Yue TL, Mckenna PJ, Gu JL, and Feuerstein GZ (1993): Interleukin-8 is chemotactic for vascular smooth muscle cells. Eur. J. Pharmacol., 240: 81-84.

11. Zozulin' D, Majchrzak A, Sobieska M, Wiktorowicz K, and Wierusz-W. (1999): Serum interleukin-8 level is increased in diabetic patients. Diabetologia, 42:117-118.

12. Mydlo, J. H., Michaeli, J., Cordon C. Goldenburg, A. and Fair W. R. (1989): Expression of transforming growth factor $a$ and epidermal growth factor receptor mRNA in neoplastic and nonneoplastic human kidney tissue. Cancer Res, 49: 34073411.

13. Damjanov, I., Mildner, B. and Knowles, B. B. (1986): Immunohistochemical

localization of the epidermal growth factor receptor in normal human tissues. Lab. Inv, 55: 588592.

14. Hahn D., Reiher, H. and Hahn, H. (1988): Phases in the early 
development of the human islet organ. Anal. Anz, 166: 69-76.

15. Glinsmann B. J. and Korc, M. (1991): Regulation of transforming growth factor- $\alpha$ mRNA expression in T3T4 human pancreatic carcinoma cells. Pancreas, 6: 142-149.

16. Al-Awadi F. M., and Gumaa, A (1987): Studies on the activity of individual plants of an antidiabetic plant mixture. Acta Diabetol. Lat, 24: 37-41.

17. Yoruk M, Kanter M, Meral I, and Agaoglu $Z$. (2004): Localization of glycogen in the placenta, fetal and maternal livers of cadmium exposed diabetic pregnant rats. Biol. Trace Elem. Res., 96: 217-226.

18. Trinder, $P$ Determination of glucose in blood using glucose oxidase with an alternative oxygen receptor, Ann. Clin. Biochem., 6: 24-27.

19. Flegg H. (1973): An investigation of the determination of serum cholesterol by an enzymatic method. Ann. Clin. Biochem. 10: 79-84.

20. Izzo C.; Grillo F. and Murador E. (1981): Improved method for determination of high-densitylipoprotein cholesterol I. Isolation of high-density lipoproteins by use of polyethylene glycol 6000 . Clin. Chem., 27(3): 371-374.

21. Friedewald, W.T.; Levy, R.I. and Fredrickson, D.S. (1973): Estimation of the concentration of LDL cholesterol in plasma without use of the preparative ultracentrifuge. Clin. Chem., 18:499

22. Fossati $P$. and Lorenzo $P$. (1982). Serum Triglycerides determined colorimetrically with an enzyme that produces hydrogen peroxide. Clin. Chem., 128: 2077-2080.

23. Veremy (2001): Am. J. Hum. Genet., 69: 413-419.

24. Chang, H. (2002). Endocr. Rev., 23:787

25. Dringen $\mathbf{R}$, and Gutterer $\mathbf{J}$. (2002). Glutathione reductase from bovine brain. Methods Enzymol., 348: 281-288.

26. Kanter M, and Meral I. (2004): Effects of Nigella sativa and Urtica dioica L. on selected mineral status and hematological values in $\mathrm{CCl}_{4}$ - treated rats. Biol Trace Elem Res., 96:263-270

27. Hammer H., Martin S., and Gerseck K. (1991): Aminoguanidine treatment inhibits development of experimental diabetic retinopathy, Proc. Nat. Acad. Sci., 88: 1155511558.

28. Rajagopal $K$, and Sasikala $K$ (2008): Antihyperglycemic and antihyperlipidemic effects of Nymphaea stellata in alloxaninduced diabetic rats. Singapore Med J., 49 (2): 137.

29. Okamoto, H. (1985): Ultrastructural aspects of streptozotocin cytotoxicity on rat pancreatic islets in vitro. BioEssays 2: 15-21.

30. Khan N, Sharma S, and Sultana S (2003): Nigella sativa (black cumin) ameliorates potassium bromate induced early events of carcinogenesis: Diminution of oxidative stress. Hum. Experimen. Toxicol ., 22 : $193-203$.

31. Inove M. Saito $Y$. and Nagase $S$ (1987): Regulation of redox status of plasma protein by mechanism and transport of glutathione and related 
compound. J. Protein Chem., 36: 169-174.

32. Akhtar MS, and Ali MR (1984): The study of hypoglycemic activity of Cuminum nigrum seeds in normal and alloxan diabetic rabbits. Planta Med., 2: 81-85.

33. El-Missiry MA. (1999): Enhanced testicular antioxidant system by ascorbic acid in alloxan diabetic rats. Comp. Biochem. Physiol. C Pharmacol. Toxicol. Endocrinol. ,124: 233237.

34. Nishi, M., Sanke, T., Nagamatsu, S., Bell, G. and Steiner, D. (1990): Islet amyloid polypeptide. J. Biol. Chem., 265: 4173-4176.

$$
\begin{aligned}
& \text { دور حبة البركة فى حماية الجرزان المحقونة بالألوكسان } \\
& \text { من مرض البوال السكرى }
\end{aligned}
$$

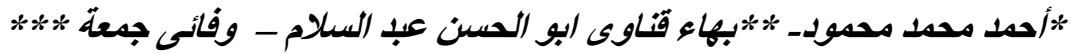

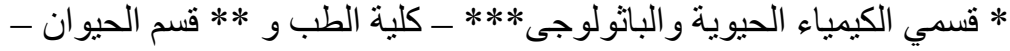

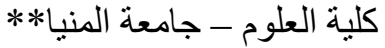

حبة البركة (أو الحبة السوداء ) هى بذور منشطة ومدرة للبول ومفيدة للربو وفى أمر اض جهاز المناعة كما ان

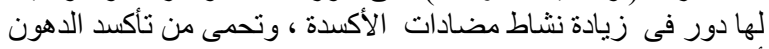

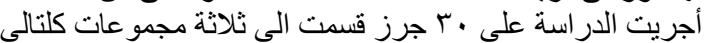

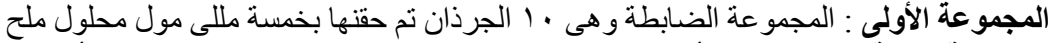

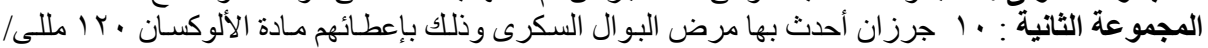

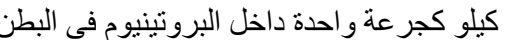

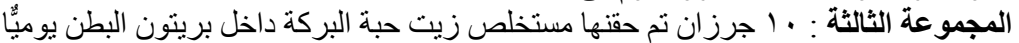

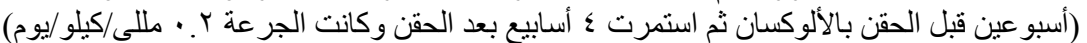

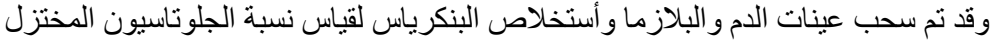

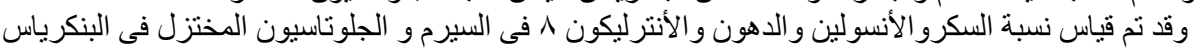

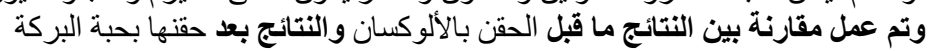

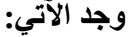

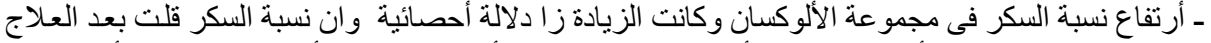

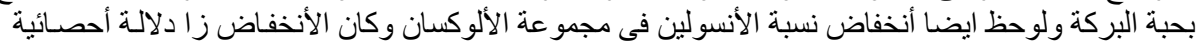

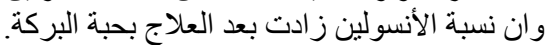

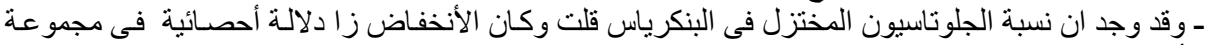

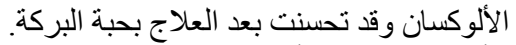

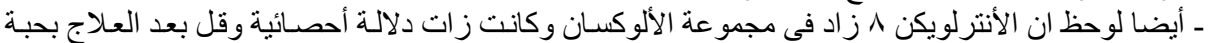

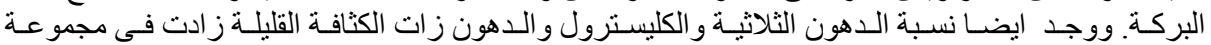

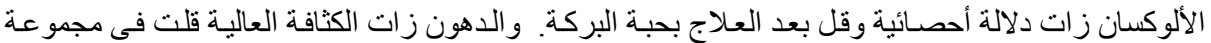

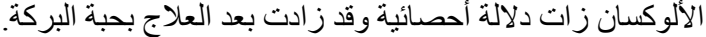

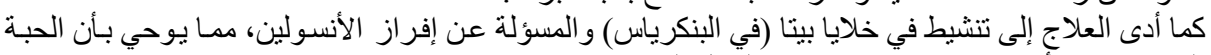

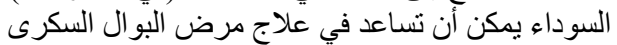

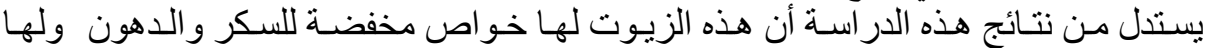
تأثير ات مضادة للأكسدة. و أنه يمكن استعمال هذه النباتات بكميات مقتنة ولفتر الت ات محددة. 